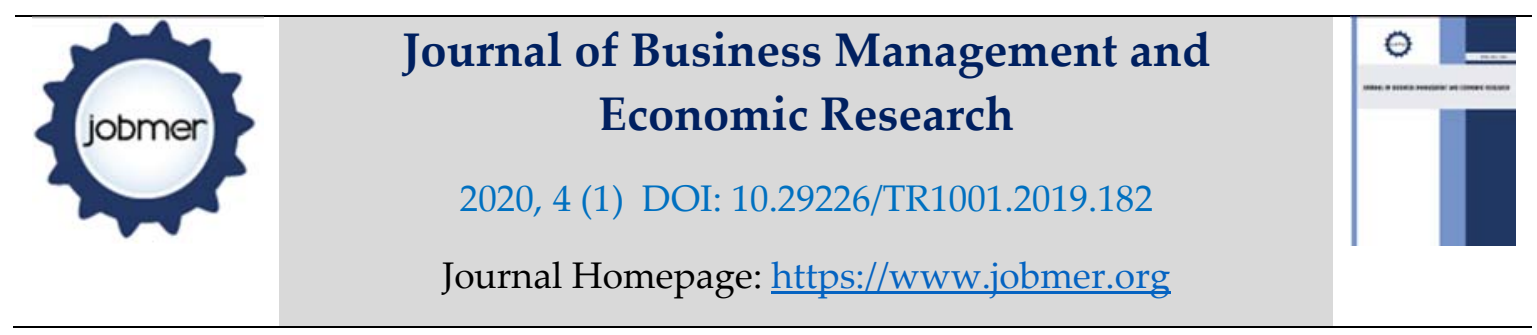

\title{
CLIENT DELAY FACTORS AFFECTING BUILDING PROJECT PERFORMANCE AMONG KUANTAN MALAYSIAN CONSTRUCTION INDUSTRY: THROUGH PARTIAL LEAST SQUARE STRUCTURAL EQUATION MODELING
}

\author{
R.M.Chung1, A.Q.Adeleke², W. A. Ajibike ${ }^{3}$ \\ 1,2,3Faculty of Industrial Management, Universiti Malaysia Pahang, Lebuhraya Tun Razak, 26300 \\ Gambang, Pahang, Malaysia \\ *Corresponding author: adekunle@ump.edu.my
}

\begin{abstract}
The construction industry has become one of the greatest income providers as it has contributed to the Gross Domestic Product (GDP) of Malaysia. However, the construction sector has been much affected by an unexpected situation such as construction delays. Delays in the construction industry are one of the common problems that happened to most construction projects. By considering all viewpoint from various parties that involve in the construction process such as contractors, client, consultant, and others, this research identified the major factor that contributes to building project delays in Kuantan, Pahang Malaysia. To address the issues above, this research paper aims: 1) to investigate the relationship between client financial difficulties and building project performance in Kuantan Construction Industry; 2) to investigate the relationship between client change order and building project performance in Kuantan construction industry, and 3) to investigate the relationship between client lack of experience and building project performance in Kuantan construction industry. Questionnaires were distributed among 131 respondents that involved in building project in Kuantan construction industry. In this research, the PLSSEM technique was used to assess both the measurement and structural models. From the PLS-SEM approach, the result shows that there is a positive relationship between client change order and building project performance among the Kuantan construction industry in Pahang, Malaysia. The client's lack of experience and building project performance was also found to be positively correlated in this study. While the result shows that client financial difficulties and building project performance has a negative relationship in Kuantan construction industry.
\end{abstract}

Keywords: Building project performance, financial difficulties, change order, lack of experience, construction industry, Malaysia.

Chung, R. M., Adeleke, A. Q. \& Ajibike, W. A. (2020). Client Delay Factors Affecting Building Project Performance Among Kuantan Malaysian Construction Industry: Through Partial Least Square Structural Equation Modeling. Journal of Business Management and Economic Research (JOBMER), Vol: 4, Issue:1, 38-55. 


\section{Introduction}

The construction industry is one of the major sectors contributing to the economic growth of a country. Among the substantial issues in the construction industry is time overrun. Construction delays assume a key role in the success or failure of a project. There are numerous factors contributing to the delays in construction projects. Delays occur almost in all construction projects, and the magnitude of these delays varies considerably from one project to another. It is important to define the real causes of delay in order to minimize, mitigate, and avoid delays in any construction project. According to Wong and Vimonsatit (2012), the delay factor is critical in the construction project, and it is crucial for all organizations to have certain knowledge with respect to this issue altogether for the project to be completed effectively, successfully and satisfactorily.

The study on project delay in construction projects is very important because time is one of three pillars (time, cost and quality) of project management, and among the three pillars of the significant issues in the construction industry is time overruns. From a study of a project, delays are expected to prompt a better understanding of the causes of the delay in construction projects. The study on road construction is an important context because roads project contributes to the growth of economic and reduction of poverty (Adeleke et al., 2019; Taofeeq et al., 2019; Seboru, 2015).

Besides, according to Sambasivan and Soon (2007) and Sweis et al. (2008), a delay in the construction project is a "universal" case, and it has turned into an ordinary part of the project's construction lifetime. Therefore, Assaf and Al-Hejji (2006) defined it as "the time overrun either beyond the completion date specified in a contract or beyond the date that the parties agreed upon for delivery of a project".

Furthermore, almost all of the construction projects are often behind schedule due to many reasons. According to Sweis, et al. (2008), delays often occur due to poor management of various factors related to contractor, client, consultants, material, labor, and equipment of the projects. In addition, Sweis et al. (2008) and Yang et al. (2013), opined that the general conditions including climate, law and order circumstances and the economic conditions also cause a delay in project completions. Unfortunately, even these days, with all the cutting-edge innovation and the incredible understanding of project management and engineering techniques, the delays issues have not been settled yet.

Also, Youcef, Zidane, Bjorn \& Andersen (2018), maintained that a project often confronted with delays and unnecessary utilization of time because of several factors and reasons, and thereby experience hardships 
effects of negative consequences. The authors claimed that the ten most important universal delay factors such as contractor's financial difficulties, sponsor/ owner/ client's financial difficulties, changes in design during construction/change orders, inadequate contractor experience/building methods and approaches, delays in contractor's payment, poor planning and scheduling, poor site management and supervision, incomplete or improper design, resources shortage (human resources, machinery, equipment), poor labour productivity and shortage of skills (Abulhakim \& Adeleke, 2019; Bamgbade et al., 2019).

In addition, from the study of Assaf and Al-Hejji (2006), $76 \%$ of the contractors showed that the average time overrun is between $10 \%$ and $30 \%$ of the initial planned duration, while about $56 \%$ of the consultants determined a similar rate. Besides, a study from Faridi and El-Sayegh (2006) uncovered that $50 \%$ of the construction projects in the UAE experience delays and they were not completed on schedule. Similar research investigates the factors of delays and their effects in the literature from a total of 45 countries around the world.

Based on Yang et al. (2013), from the last 40 years, huge consideration has been paid to identify possible delays causes. To identify the causes, some authors such as Doloi, Sawhney, and Rentala (2012), Kazaz et al. (2012), Sambasivan and Soon (2007), Assaf and Al-Hejji (2006), Faridi and El-Sayegh (2006), and Chan and Kumaraswamy (1997), have used quantitative methods like questionnaires, while others such as Asnaashari et al. (2009) have used wholly qualitative methods like interviews to identify the delay causes. Moreover, this study will provide insights into the various types of delays in construction projects, their respective causes and ways to ameliorate the effect of delays in construction projects. Findings from this study will be of immense contribution to the project managers in overcoming the issues which cause delay and to avoid the negative outcomes of delay in the construction project.

\section{Literature Review}

\subsection{Overview of Malaysian Construction Industries}

Since Malaysians gained independence in 1957, Malaysia has been engaged in a series of construction activities. Malaysia's construction sector recorded the value of construction work done to the tune of RM36.5 billion in the final quarter of 2018. The construction value work done in the final quarter of 2018 recorded a moderate growth of 4.1 percent year-on-year to a record of RM36.5 billion (Q3 2018: RM36.3 billion). The expansion in construction value work done was a result of effective growth in the civil 
engineering work, special trades activities and non-residential buildings sub-sectors, which grew by 14.3 percent, 8.2 percent, and 2.5 percent respectively (Adeleke et al., 2019; Taofeeq et al., 2019). Nonetheless, the Residential buildings' sub-sector declined to 9.2 percent. In terms of contributions, the civil engineering sub-sector kept on dominating the performance of value of construction work done with 42.6 percent share, followed by non-residential buildings (28.4\%), residential buildings (24.2\%) and special trades activities (4.8\%). The private sector kept on propelling the construction activity with 56.2 percent share (RM20.5 billion) as compared to the public sector with 43.8 percent (RM16.0 billion). The value of construction work done for 2018 added up to RM145.5 billion, grew by 5.1 percent as compared to RM138.5 billion in the previous year (Department of Statistics Malaysia, 2018; Hassan \& Adeleke, 2019).

Basically, the construction industry is one of the top four sectors contributing to the economy of Malaysia behind agriculture, services and manufacturing sectors. Besides, there are several classifications of construction industries in Malaysia. These are residential construction, non-residential construction, and civil construction or infrastructure. In addition, the Construction Industry Development Board (CIDB) is one of the agencies of the Malaysian government championed establish to support and encourage the development, enhancement, and growth of the construction industry. All the construction companies operating in Malaysia are required to register their companies with the CIDB for them to operate in any part of Malaysia. They are classified into 7 categories (G1 to G7) based on their economic position, hightech competence and record documents (Construction Industry Development Board, 2014; Hassan et al., 2019)

According to Mhlanga and Mpofu (2016), financial difficulties refer to a condition in which a client cannot meet, or has difficulty paying off its financial obligations to the contractors involved in a project. During the construction, the client may face some financial problems arise from unanticipated emergencies or financial mismanagement, global financial crisis.

According to Al-Hammadi and Nawab (2016), change orders are a component of the change management process or change in the requirements in which is caused by the clients in the project implementation. The construction process is assumed to be complex and is associated with numerous changes. These changes typically lead to the issuance of change orders. Change order in the construction project is a work that has been added or removed from the original scope of a contract that changes the initial value of the contract or the date of completion. Certainly, a change order is a problem for the project in terms of extra costs and extra time (Azman \& Adeleke, 2018). 
Nyoni \& Bonga (2016) claimed that the client's lack of experience in which the client does not have enough experience, especially a fresh developer. Most of the time, a client facing a problem and do not know how to solve it immediately because of a lack of experience. Therefore, due to the inexperience of clients in construction projects, it will lead to delays in construction projects where it can lengthen schedule (Adeleke et al., 2018; González et al., 2013).

\section{$2.2 \quad$ Conceptual Framework}

This research is conducted using the specified model with clearly defined independent and dependent variables. Based on the conceptual framework, the independent variables in this research are the clients' delay factors which are financial difficulties, change order, and lack of experience and the dependent variable is building project performance in the construction industry. Thus, the framework shows the relationships between these variables, which the findings will indicate whether they are positive or negative relationships.

$\underline{\text { Client Delay Factors }}$

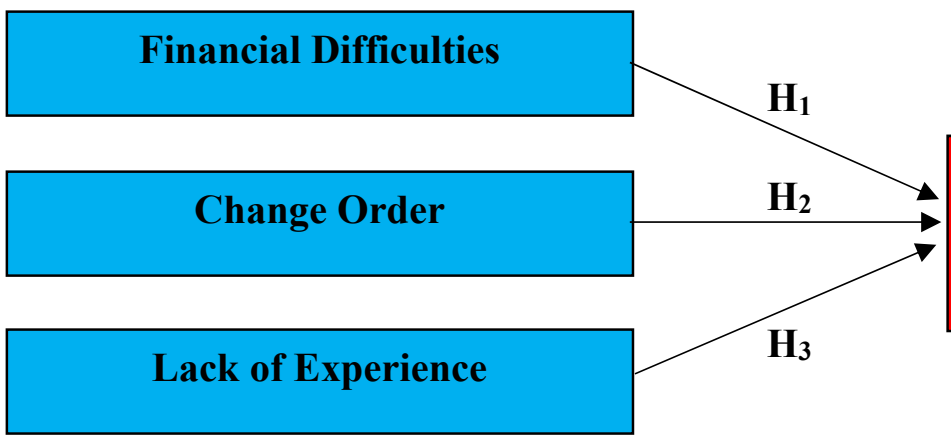

Construction Industry

Building Project Performance

\section{Figure 1: Research Framework}

\subsection{Relationship between financial difficulties and building project performance}

A delay in construction projects is a common issue and very costly. This study addresses the issues of financial-related delays in construction projects. It identifies the root causes and scrutinizes the suitable mitigation actions of financial-related project delays. Four main factors were identified in the literature, 
such as late payment, poor cash flow management, insufficient financial resources, and financial market instability (Adeleke et al., 2018; Taofeeq et al., 2019).

A survey conducted by Mezher and Tawil, (1998) on the causes of delays in the construction industry in Lebanon from the perspective of the clients, contractors and architectural/engineering firms, It was found that clients are more concerned with financial issues.

Similarly, Chan and Kumaraswamy (1994) identified a client's financial difficulties as another cause of delay. If a client encounters financial difficulties arising from unanticipated emergencies or financial mismanagement, funds may be unavailable when needed for the construction work. Therefore, it is hypothesized thus:

Hypothesis 1: There is a positive relationship between financial difficulties and building project performance.

\subsection{Relationship between change order and building project performance}

According to Hanna and Gunduz (2004), change orders have long been an inherent part of the construction industry. It is hardly found that a construction project is completed without a change that generally arises as a result of the causes attributed to the diverse parties involved in the execution of the project. Once, it has been recognized that the change is formally regulated by issuing an amending order that may have an impact on both the cost and duration of the project.

The significance of change order as a cause of cost overruns and time is also explored by Oladapo (2007). Changes at each stage or on a steady basis in construction project disrupt the project schedule as well as supplementary work (Adeleke et al., 2016; Bamgbade et al., 2019; Jadhav and Bhirud, 2015).

Osman et al. (2009), defined the change as any deviation from a defined scope and schedule. The word "Change Order" express strong feelings of negativity to all those involved in construction projects. In some cases, contractors consider change orders to disrupt work-flow and require additional documentation and duration. Therefore, it is hypothesized thus:

Hypothesis 2: There is a positive relationship between change order and building project performance. 
Journal of Business Management and Economic Research (JOBMER), vol.4, issue.1, pp.38-55

\subsection{Relationship between lack of experience and building project performance}

Koushik and Kartam, (2005) identified that the client's lack of experience in construction projects as a cause of delay. A fresh developer may face a problem and not know how to solve it immediately because of his lack of experience. While he tries to find ways to solve the problem, work may stop.

As stated by Nyoni \& Bonga (2016) client with a lack of experience is the client who does not have enough experience especially a fresh developer. Most of the time, a client facing a problem and do not know how to solve it immediately because of no experience.

Therefore, due to the inexperience clients in the construction projects, it will cause delays in construction projects where it can lengthen schedule, increase project costs and jeopardize quality and safety (Malik \& Adeleke, 2018). Furthermore, delays result in huge cost overruns and hinder economic growth. Therefore, it is hypothesized thus:

Hypothesis 3: There is a positive relationship between lack of experience and building project performance.

\section{Methodology}

This study used a cross-sectional research design by using a structured questionnaire, the data were collected at a single-point-in-time (Sekaran \& Bougie, 2013). Besides, a proportionate stratified random sampling technique was employed for selecting samples in this research. Also, the quantitative research approach was used in this study, as this is mostly adopted methods in social science research (Sekaran, Robert and Brain, 2001; Adeleke et al., 215). This research was conducted among building project contractors in the Kuantan Pahang construction industries. The total number of 89 questionnaires were distributed to the sampled companies in Kuantan, Pahang.

\subsection{Instrument Design}

The quantitative method was used in this research as it is more structured than the qualitative method of data collection. Hence, the data was collected using the questionnaire because it was found to be easier for the collection of data from the respondents. The answers to the questions were recorded by taking input from the respondents and without the need for an interview. Five-point Likert scale was adopted to measure the independent and dependent variables which range from (1) very low, (2) low,(3) medium,(4) high, to (5) very high, following (Rahman \& Adeleke, 2018). According to Sekaran (2003) and Sekaran \& 
Bougie (2009), to compute the standard deviation and the mean feedback on the variables and the midpoint of the scale a researcher must adopt the rating scale. In analyzing the data, SPSS software version 22.0 was used for respondents' demographic characteristics such as position, company year of existence, gender, company's prime location, company's ownership, work experience, number of full-time employees and company ownership (Ismayana \& Adeleke, 2020). The data analysis adopted for both independent and dependent variables was Smart PLS version 3.0. All the variables in this research are multidimensional as presented in Table 1.

Table 1: Source of Measurement

\begin{tabular}{lllll}
\hline S/N & Constructs & Dimension & Source & Remarks \\
\hline 1 & Client delay factors & Financial Difficulties & Mhlanga and Mpofu & Adapted \\
& & Change Order & $(2016)$, \\
& Lack of Experience & Al-Hammadi and Nawab & \\
& & $(2016)$, & \\
& & Nyoni \& Bonga (2016) & \\
& & Yang (2007) & Adapted \\
& \multirow{2}{*}{ Construction project } & Building project & & \\
& & Performance & &
\end{tabular}

\section{Results and Discussions}

\subsection{Data Collection and Sample}

131 sets of questionnaire were distributed to the building construction companies in Kuantan, Pahang. However, 89 sets of questionnaires were returned after the distribution which accounted for $67.94 \%$ for the response rate and is acceptable because the sample size for this research is 89 . Table 2 shows a summary of the demographic characteristics of respondents for this research. 
Journal of Business Management and Economic Research (JOBMER), vol.4, issue.1, pp.38-55

Table 2: Summary of Demographic Scales of Respondents

\begin{tabular}{|c|c|c|c|}
\hline Type & Items & Frequency (N) & Percentage $(\%)$ \\
\hline \multirow{5}{*}{ Position } & Contract manager & 8 & 9.00 \\
\hline & Project manager & 19 & 21.00 \\
\hline & Safety Officer & 6 & 7.00 \\
\hline & Worker & 26 & 29.00 \\
\hline & Others & 30 & 34.00 \\
\hline \multirow{4}{*}{ Working experience } & $1-3$ years & 49 & 49.00 \\
\hline & $4-6$ years & 24 & 24.00 \\
\hline & $7-9$ years & 8 & 8.00 \\
\hline & $>10$ years & 8 & 8.00 \\
\hline \multirow{2}{*}{ Gender } & Male & 59 & 66.00 \\
\hline & Female & 30 & 34.00 \\
\hline \multirow{4}{*}{ Type of project } & Residential building & 29 & 32.00 \\
\hline & Educational building & 7 & 8.00 \\
\hline & Commercial Building & 23 & 26.00 \\
\hline & Others & 30 & 34.00 \\
\hline Company Ownership & Local & 89 & 100.00 \\
\hline \multirow{4}{*}{ Company Existence } & $1-4$ years & 3 & 3.00 \\
\hline & 5-6 years & 15 & 15.00 \\
\hline & $7-9$ years & 8 & 8.00 \\
\hline & $>10$ years & 63 & 63.00 \\
\hline \multirow{4}{*}{ Size of Company } & Micro (<10 employees) & 1 & 1.00 \\
\hline & Small (10-50 employees) & 31 & 31.00 \\
\hline & Medium (51-250 employees) & 31 & 31.00 \\
\hline & Large (>250 employees) & 26 & 26.00 \\
\hline
\end{tabular}

\subsection{Measurement Model}

Before examining the hypothesis, the measurement model and the outer model were tested through the partial least square structural equation modeling (PLS-SEM) technique. Figure 2 shows the model of this research with the structural dimensions below (Sabodin \& Adeleke, 2018). 


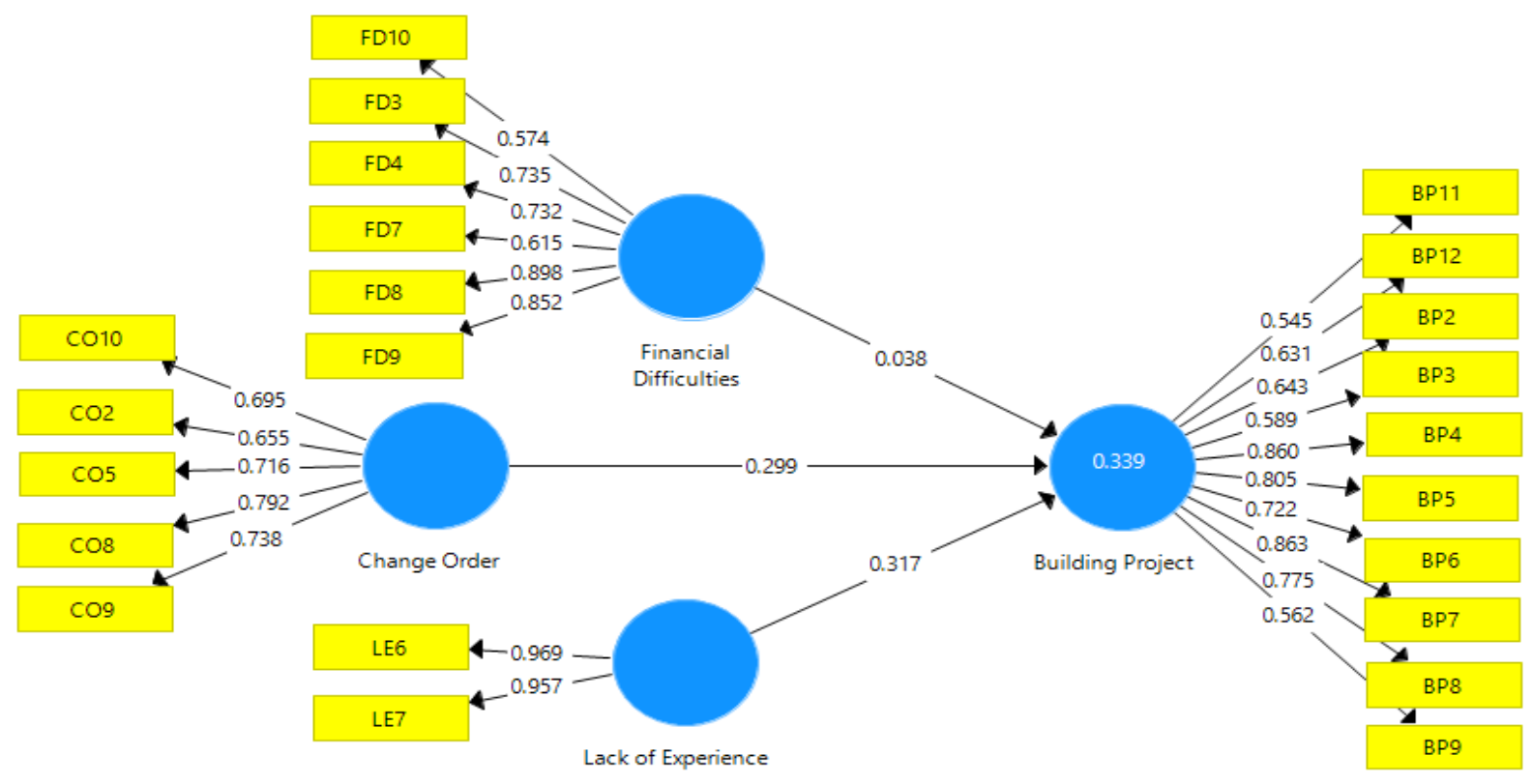

Figure 2: Measurement model

Table 3 shows the content validity of the measurements used which was explained in two ways. Firstly, there are high loading in the items on their respective constructs when related to other constructs. Secondly is the loading of the items were significantly loading on their respective constructs affirming the content validity of the measure used in this research (Adeleke et al., 2016; Taofeeq et al., 2020; Chow and Chan, 2008). 
Journal of Business Management and Economic Research (JOBMER), vol.4, issue.1, pp.38-55

Table 3: Factor Analysis and Loading of the items (Cross Loading)

\begin{tabular}{lcccc}
\hline & BP & CO & FD & LE \\
\hline BP11 & $\mathbf{0 . 5 4 5}$ & 0.224 & 0.114 & 0.272 \\
BP12 & $\mathbf{0 . 6 3 1}$ & 0.316 & 0.114 & 0.259 \\
BP2 & $\mathbf{0 . 6 4 3}$ & 0.227 & 0.14 & 0.225 \\
BP3 & $\mathbf{0 . 5 8 9}$ & 0.314 & 0.317 & 0.194 \\
BP4 & $\mathbf{0 . 8 6}$ & 0.54 & 0.35 & 0.531 \\
BP5 & $\mathbf{0 . 8 0 5}$ & 0.416 & 0.323 & 0.423 \\
BP6 & $\mathbf{0 . 7 2 2}$ & 0.292 & 0.183 & 0.148 \\
BP7 & $\mathbf{0 . 8 6 3}$ & 0.48 & 0.332 & 0.52 \\
BP8 & $\mathbf{0 . 7 7 5}$ & 0.454 & 0.387 & 0.58 \\
BP9 & $\mathbf{0 . 5 6 2}$ & 0.216 & 0.147 & 0.12 \\
CO10 & 0.313 & $\mathbf{0 . 6 9 5}$ & 0.246 & 0.402 \\
CO2 & 0.282 & $\mathbf{0 . 6 5 5}$ & 0.602 & 0.39 \\
CO5 & 0.367 & $\mathbf{0 . 7 1 6}$ & 0.675 & 0.455 \\
CO8 & 0.447 & $\mathbf{0 . 7 9 2}$ & 0.63 & 0.541 \\
CO9 & 0.448 & $\mathbf{0 . 7 3 8}$ & 0.192 & 0.508 \\
FD10 & -0.001 & 0.128 & $\mathbf{0 . 5 7 4}$ & -0.02 \\
FD3 & 0.239 & 0.409 & $\mathbf{0 . 7 3 5}$ & 0.27 \\
FD4 & 0.125 & 0.375 & $\mathbf{0 . 7 3 2}$ & 0.139 \\
FD7 & 0.186 & 0.457 & $\mathbf{0 . 6 1 5}$ & 0.333 \\
FD8 & 0.408 & 0.67 & $\mathbf{0 . 8 9 8}$ & 0.523 \\
FD9 & 0.331 & 0.467 & $\mathbf{0 . 8 5 2}$ & 0.331 \\
LE6 & 0.603 & 0.448 & $\mathbf{0 . 9 6 9}$ \\
LE7 & 0.647 & 0.424 & $\mathbf{0 . 9 5 7}$ \\
\hline & 0.465 & & & \\
\hline
\end{tabular}

The convergent validity is considered to be the extent to which a group of variables converges to measure a specific concept. To establish the convergent analysis, there are three criteria that were examined at once. These are the factor loadings (FL), composite reliability (CR) and average variance extracted (AVE). Furthermore, all items of loading were tested which is acceptable for all items and its values must be more 
than 0.5 following the literature on the multivariate approach. Besides, the other criterion is the composite reliability $(\mathrm{CR})$ to examine convergent validity. It referred to the extent to which a set of items regularly indicates the latent construct (Hair et. al, 2010). In Table 4, the values of CR and AVE were tested. The values of CR ranges from around 0.840 to 0.960 which is more than expected values of 0.7 . These results show the AVE measures the variance that covered by indicators in relation to the variance assigned to the measurement errors. Barclay et. al (1995), stated that the AVE value is at least 0.5, then a set of items have enough convergence to measure the concerned construct. So, the AVE value for this research ranged from 0.500 to 0.900 that can be categorized as a good level of the construct validity of measurement employed (Taofeeq et al., 2019; Omer \& Adeleke, 2019).

Table Hata! Belgede belirtilen stilde metne rastlanmadı.: The Convergent Validity Analysis

\begin{tabular}{|c|c|c|c|c|c|}
\hline Construct Dimensions & Items & Loading & $\begin{array}{l}\text { Composite } \\
\text { Reliability }\end{array}$ & AVE & $\begin{array}{c}\text { Cronbach's } \\
\text { Alpha }\end{array}$ \\
\hline \multirow{10}{*}{$\begin{array}{l}\text { Building Project } \\
\text { Performance }\end{array}$} & BP11 & 0.545 & \multirow{10}{*}{0.908} & \multirow{10}{*}{0.503} & \multirow{10}{*}{0.893} \\
\hline & BP12 & 0.631 & & & \\
\hline & BP2 & 0.643 & & & \\
\hline & BP3 & 0.589 & & & \\
\hline & BP4 & 0.86 & & & \\
\hline & BP5 & 0.805 & & & \\
\hline & BP6 & 0.722 & & & \\
\hline & BP7 & 0.863 & & & \\
\hline & BP8 & 0.775 & & & \\
\hline & ВР9 & 0.562 & & & \\
\hline \multirow{5}{*}{ Change Order } & $\mathrm{CO} 10$ & 0.695 & \multirow{5}{*}{0.843} & \multirow{5}{*}{0.52} & \multirow{5}{*}{0.771} \\
\hline & $\mathrm{CO} 2$ & 0.655 & & & \\
\hline & $\mathrm{CO} 5$ & 0.716 & & & \\
\hline & $\mathrm{CO} 8$ & 0.792 & & & \\
\hline & CO9 & 0.738 & & & \\
\hline \multirow{6}{*}{ Financial Difficulties } & FD10 & 0.574 & \multirow{6}{*}{0.879} & \multirow{6}{*}{0.553} & \multirow{6}{*}{0.851} \\
\hline & FD3 & 0.735 & & & \\
\hline & FD4 & 0.732 & & & \\
\hline & FD7 & 0.615 & & & \\
\hline & FD8 & 0.898 & & & \\
\hline & FD9 & 0.852 & & & \\
\hline \multirow{2}{*}{ Lack of Experience } & LE6 & 0.969 & \multirow{2}{*}{0.963} & \multirow{2}{*}{0.928} & \multirow{2}{*}{0.923} \\
\hline & LE7 & 0.957 & & & \\
\hline
\end{tabular}


To the construct validity of the outer model, the discriminant validity is essentially established. The discriminant validity is compulsory to be tested before the hypothesis is examined through path analysis. The measurement revealed that the degree to which items differ among constructs. Then, the discriminant validity shown that items used different constructs does not overlap (Subani \& Adeleke, 2020). As illustrated in Table 5, the square root of AVE for all constructs was replaced at the diagonal elements of the correlation matrix. Therefore, the discriminant validity of the outer model for this study was confirmed where the diagonal elements in the table were higher than the other elements of the column and row where they are located. From the testing made above for the construct validity of the outer model, it is believed that the obtained results pertaining to the hypotheses testing should be highly reliable and valid (Samsudin et al., 2020; Bamgbade et al., 2019; Jamil \& Adeleke, 2018).

Table 1: Discriminant Validity Analysis

\begin{tabular}{lcccc}
\hline & BP & CO & FD & LE \\
\hline Building Project performance & $\mathbf{0 . 7 0 9}$ & & & \\
Change Order & 0.528 & $\mathbf{0 . 7 2 1}$ & & \\
Financial Difficulties & 0.372 & 0.639 & $\mathbf{0 . 7 4 3}$ & \\
Lack of Experience & 0.528 & 0647 & 0.454 & $\mathbf{0 . 9 6 3}$ \\
\hline
\end{tabular}

After confirming the goodness of the outer model, the next step was to investigate the relationships that were hypothesized in the study. PLS Algorithm was run to investigate the hypothesized model through Smart PLS. The path coefficient was gained by running PLS Algorithm which is depicted in Table 6 below. The result showed that the change order (CO) variable has a positive relationship with building project performance $(\beta=0.299, \mathrm{t}=1.754, \mathrm{p}=0.040)$. Therefore, the $\mathrm{H}_{1}$ : the effect of a change order on building project performance was supported. The second hypothesis $\mathrm{H}_{2}$ : financial difficulties (FD) show negative relationship on building project performance $(\beta=0.038, t=0.304, p=0.381)$. While, the third hypothesis $\mathrm{H}_{3}$ : lack of experience (LE), also has a positive relationship with building project performance $(\beta=0.317, t=$ 2.216, $\mathrm{p}=0.013$ ), (Adeleke et al., 2015). 
Journal of Business Management and Economic Research (JOBMER), vol.4, issue.1, pp.38-55

Table 6: Results of the Inner Structural Model

\begin{tabular}{lllllll}
\hline Items & Constructs/variables & Beta & S/E & T-value & P-value & Findings \\
\hline $\mathrm{H}_{1}$ & $\mathrm{CO}->\mathrm{BP}$ & 0.299 & 0.170 & 1.754 & 0.040 & Supported \\
$\mathrm{H}_{2}$ & $\mathrm{FD}>\mathrm{BP}$ & 0.038 & 0.124 & 0.304 & 0.381 & Not Supported \\
$\mathrm{H}_{3}$ & LE -> BP & 0.317 & 0.143 & 2.216 & 0.013 & Supported \\
\hline
\end{tabular}

As for size effect, Cohen (1988) suggested that the criteria of effect size is less than $0.02(0.02=$ small, $0.15=$ medium, 0.35 = high). From Table 4.7, the effective size of the change order is medium, meanwhile, the effect size of financial difficulties and lack of experience are both small. The calculation of effect size is as follow:

$$
\text { Effect size }(\mathfrak{f})=\frac{\mathrm{R} 2 \text { incl }-\mathrm{R} 2 \text { excl }}{1-\mathrm{R} 2 \text { incl }}
$$

Table 7: Direct Effect IV-DV

\begin{tabular}{lcccc}
\hline R-squared & Included & Excluded & f-squared & Effect size \\
\hline Change Order & 0.339 & 0.314 & 0.0378 & small \\
Financial Difficulties & 0.339 & 0.338 & 0.0015 & none \\
Lack of Experience & 0.339 & 0.275 & 0.0968 & small \\
\hline
\end{tabular}

\section{Conclusion}

This research is focused on client financial difficulties, change order, lack of experience as factors of delays affecting building project performance in the Kuantan construction industries. The findings of this study will help future researchers who want to conduct research to gain information from previous research regarding the construction field.

Thus, this research will not only benefit the academic world but will equally be of immense benefit to those professionals in the construction industries as well especially those that involved and experienced delay in their project in order to mitigate or eliminate the effects of construction projects delay not only for building projects but also for all types of project in the construction projects. 


\section{Acknowledgment}

Authors of this study acknowledge the research funding from Universiti Malaysia Pahang managed by

PNI, [Grant code: RDU190390].

\section{References}

Abd El-Razek, M.E; Bassiouni, H.A; Mobarak, M.A; (2008). “Causes of Delay in Building Construction Projects in Egypt" J. Constr. Eng. Manage. 2008.134:831-841.

Abdul-Rahman H, Takim R, Min WS. Financial-related causes contributing to project delays. J Retail Leis Prop. 2009;8(3):225-238. DOI:10.1057/rlp.2009.11.

Abulhakim, N., \& Adeleke, A. Q. (2019). The Factors Contributing to Accident Occurrence on Malaysia Building Projects through Partial Least Square Structural Equation Modeling. Social Science and Humanities Journal, 1096-1106.

Adeleke, A. Q. and Bahaudin, A. Y. and Kamaruddeen, A. M. and Bamgbaded, J. A. and M., Waris and Panda, Sitansu and Afolabi, Yakibi Ayodele (2019) An Empirical Analysis of Organizational External Factors on Construction Risk Management. International Journal of Supply Chain Management (IJSCM), 8 (1).pp. 932-940

Adeleke, A. Q., Bamgbade, J. A., Salimon, M. G., \& Lee, C. K. (2019). Project Management Performance and Its Influence on Malaysian Building Projects. KnE Social Sciences, 313-329.

Adeleke, A. Q., Windapo, A. O., Khan, M. W. A., Bamgbade, J. A., Salimon, M. G.,\& Nawanir, G. (2018). Validating the Influence of Effective Communication, Team Competency and Skills, Active Leadership on Construction Risk Management Practices of Nigerian Construction Companies. The Journal of Social Sciences Research, 460-465.

Adeleke, A. Q., Bahaudin, A. Y., \& Kamaruddeen, A. M. (2016, August). Rules and regulations as potential moderator on the relationship between organizational internal and external factors with effective construction risk management in Nigerian construction companies: a proposed framework. In AIP Conference Proceedings (Vol. 1761, No. 1, p. 020008). AIP Publishing.

Adeleke, A. Q., Nasidi, Y., \& Bamgbade, J. A. (2016). Assessing the Extent of Effective Construction Risk Management in Nigerian Construction Companies. Journal of Advanced Research in Business and Management Studies, 3(1), 1-10.

Adeleke$^{1}$, A. Q., Bahaudin, A. Y., \& Kamaruddeen, A. M. (2015). A Partial Least Square Structural Equation Modeling (PLS SEM) Preliminary Analysis on Organizational Internal and External Factors Influencing Effective Construction Risk Management among Nigerian Construction Industries. Rev. Téc. Ing. Univ. Zulia, 38(143), 143-55.

Adeleke, A., Bahaudin, A., \& Kamaruddeen, (2015) A Level of Risk Management Practice in Nigeria Construction Industry-From a Knowledge Based Approach. Journal of Management Marketing and Logistics, 2(1), 12-23

Aftab HM. Contractor perspective on time overrun factors in Malaysian construction projects. Int J Sci Environ Technol. 2014;3(3):1184-1192. 
Journal of Business Management and Economic Research (JOBMER), vol.4, issue.1, pp.38-55

Al-Momani AH. (2000), "Construction delay: a quantitative analysis". International Journal of Project Management;18(1):51-9.

Assaf SA, Al-Khalil M, Al-Hazmi M. (1995), "Causes of delays in large building construction projects". ASCE J Manage Eng;11(2): 45-50.

Assaf, S., and Al-Hejji, S. (2006), "Causes of delay in large construction projects", International Journal of Project Management, 24, 349-357.

Azman, N. A. S. M., \& Adeleke, A. Q. (2018). Effect of Time Overruns on Apartment Building among Kuantan Malaysian Construction Industries. Journal of Advanced Research in Applied Sciences and Engineering Technology, 10 (1), 41-47.

Bamgbade, J. A., Salimon, M. G., Adeleke, A. Q., \& Nasidi, Y. (2019). Contractor's Technology Acceptance for Firm Sustainability Performance. KnE Social Sciences, 1084-1101.

Bamgbade, J. A., Nawi, M. N. M., Kamaruddeen, A. M., Adeleke, A. Q., \& Salimon, M. G. (2019). Building sustainability in the construction industry through firm capabilities, technology and business innovativeness: empirical evidence from Malaysia. International Journal of Construction Management, $1-16$.

Bamgbade, J. A., Kamaruddeen, A. M., Nawi, M. N. M., Adeleke, A. Q., Salimon, M. G., \& Ajibike, W. A. (2019). Analysis of some factors driving ecological sustainability in construction firms. Journal of cleaner production, 208, 1537-1545.

Chin, W. W. (1998). The partial least squares approach to structural equation modelling. Modern methods for business research, 295(2), 295-336.

Chow, W. S., \& Chan, L. S. (2008). Social network and shared goals in organizational knowledge sharing, Information Management, 45, 7, 24-30.

Cohen, J. (1988). Statistical power analysis for the behavioral sciences (2nd ed.). Hillsdale, NJ: Lawrence Erlbaum.

De Blois M, Herazo-Cueto B, Latunova I, Lizarralde G. Relationships between construction clients and participants of the building industry: Structures and mechanisms of coordination and communication. Archit Eng Des Manag. 2011;7(1):3-22. DOI:10.3763/aedm.2009.0110.

Faridi AS, El-Sayegh SM. Significant factors causing a delay in the UAE construction industry. Constr Manag Econ. 2006;24(11):1167-1176. DOI:10.1080/01446190600827033 Fugar F, Agyakwah-baah A. Delays in Building Construction Projects in. 2003.

Hamzah A-R, Chen W, Takim R, Wong SM. Project Schedule Influenced by Financial Issues : Evidence in Construction Industry. Sci Res Essay. 2011;6(1):205-212. DOI:10.5897/SRE10.989.

Hareru W, Neeraj Jha K, Koshe W, Jha KN. Investigating Causes of Construction Delay in Ethiopian Construction Industries. J Civil, Constr Environ Eng. 2016;1(1):18-29. DOI:10.11648/j.jccee.20160101.13.

Hassan, A. K., \& Adeleke, A. Q. (2019). The Effects of Project Triple Constraint on Malaysia Building Projects. Social Science and Humanities Journal, 1222-1238. 
Journal of Business Management and Economic Research (JOBMER), vol.4, issue.1, pp.38-55

Hassan, A. K., Adeleke, A. Q., \& Hussain, S. (2019). Partial Least Square Structural Equation Modeling: An Approach to the Influence of Project Triple Constraint on Building Projects among Malaysian Construction Industries. Social Science and Humanities Journal, 1445-1464.

Ismail I, Abdul Rahman I, Memon AH. Study of factors causing time and cost overrun throughout the life cycle of construction projects. Proceeding Malaysian Tech Univ Conf Eng Technol. 2013;(3-4):3-4.

Ismayana, M. P., \& Adeleke, A. Q. (2020). The Influence of Organizational Culture on Construction Risk Management among Kuantan Malaysian Construction Industry: A Partial Least Square Structural Equation Modeling Approach. Social Science and Humanities Journal, 1693-1704.

Kumaraswamy M, Chan D.(1998)., "Contributors to construction delay". Construct Manage Econom;16(1):17-29.

Malik, N. S. A., \& Adeleke, A. Q. (2018). The Effect of Organizational Culture on Material Risk among Malaysian Construction Industries. Journal of Advanced Research in Applied Sciences and Engineering Technology, 10 (1), 34-40.

Mei Kei H. Department of Statistics Malaysia Press Release. Dep Stat Malaysia. 2018;(June):5-9. DOI:10.1017/CBO9781107415324.004.

N.D Jamil, A.Q. Adeleke (2018). The relationship between team competency and design risk management among construction industries in Kuantan. Journal of Advanced Research in Applied Sciences and Engineering Technology, 10 (1), 77-81.

Omer, M. S., \& Adeleke, A. (2019). Systematic Critical Review of Risk Management in Malaysian Construction Companies. Journal of Humanities and Social Sciences Studies (JHSSS) Vol, 1.

Rahman, N. F. A., \& Adeleke, A. Q. (2018). The Relationship between Effective Communication and Construction Risk Management among Kuantan Malaysian Construction Industries. Journal of Advanced Research in Applied Sciences and Engineering Technology, 10 (1), 18-24.

Sabodin, N., \& Adeleke, A. Q. (2018). The Influence of Government Regulation on Waste Reduction Among Kuantan Malaysian Construction Industry. Journal of Advanced Research in Applied Sciences and Engineering Technology, 10 (1), 72-76.

Sambasivan M, Soon YW. Causes and effects of delays in the Malaysian construction industry. Int J Proj Manag. 2007;25(5):517-526. DOI:10.1016/j.ijproman.2006.11.007.

Samsudin, N. S. A., Adeleke, A. Q., \& Ajibike, W. A. (2020). Effects of Contractors' Delay Factors on Building Project Performance Among Kuantan Malaysian Construction Industry. Social Science and Humanities Journal, 1705-1715.

Sekaran, U. \& Bougie, R. (2013). Research Methods for Business: A Skill Building Approach. New Jersey: John Willey and Sons. Inc.

Sekaran, U. (2003). Research methods for business. $4^{\text {th }}$ Edn., New York: John Wiley \& Sons Inc.

Sekaran, U. and R. Bougie (2009). Research methods for business: A skill-building approach. $5^{\text {th }}$ Edn.,United Kingdom: John Wiley \& Sons Ltd.

Subani, N. A., Adeleke, A. Q., \& Bamgbade, J. A. (2020). The Role of Organizational Culture on Sustainable Construction among Malacca Malaysian Construction Industry: A Partial Least Square 
Journal of Business Management and Economic Research (JOBMER), vol.4, issue.1, pp.38-55

Approach. Social Science and Humanities Journal, 1681-1692.

Taofeeq, D. M., Adeleke, A. Q., \& Hassan, A. K. (2019). Factors Affecting Contractors risk attitude from Malaysia construction industry perspective. Social Science and Humanities Journal, 1281-1298.

Taofeeq, D. M., Adeleke, A. Q., \& Hassan, A. K. (2019). The Moderating Role of Government Policy on Contractors' Risk Attitudes in Malaysia Construction Companies. Social Science and Humanities Journal, 1261-1280.

Taofeeq, D. M., \& Adeleke, A. Q. (2019). Factor's Influencing Contractors Risk Attitude in the Malaysian Construction Industry. Journal of Construction Business and Management, 3(2), 59-67.

Taofeeq, D. M., Adeleke, A. Q., \& Lee, C. K. (2020). The synergy between human factors and risk attitudes of Malaysian contractors': Moderating effect of government policy. Safety science, 121, 331-347.

Taofeeq, D. M., Adeleke, A. Q., \& Lee, C. K. (2019). Individual factors influencing contractors' risk attitudes among Malaysian construction industries: the moderating role of government policy. International Journal of Construction Management, 1-20. 